\title{
NOTULEN
}

VAN DE

BESTUURS. EN ALGEMEENE VERGADERINGEN

VAN HET

\section{KONINKLIJK INSTITUUT}

vOOR DE

TAAL-, LAND- EN VOLKENKUNDE VAN NEDERLANDSCH-INDIË.

$$
1894-95 .
$$




\section{$351^{\text {ste }}$ BESTUURSVERGADERING,}

GEHOUDEN 19 MEI 1894.

Aanwezig de hh.: der Kinderen (Voorzitter), Pijnacker Hordijk, Canne, Niemann, Poensen . J. H. de Groot(Penningmeester), van der Lith, Kielstra ( $w^{\mathrm{d}}$ Secretaris).

Afwezig, met kennisgeving, de hh.: Kern, J. J. M. de Groot, van Limburg Stirum en Wijnmalen.

De notulen der Bestuursvergaderingen van 17 Februari en 21 April worden gelezen en goedgekeurd.

Die der Algemeene Vergadering van 24 Februari 1894 worden voorloopig door het Bestuur vastgesteld.

De President doet mededeeling der sedert de vorige Vergadering ingekomen boekwerken, waaronder (van den Minister van Koloniën) het door het Aardrijkskundig Genootschap uitgegeven werk van Dr. Jul. Jacobs over het Familie- en Kampongleven in Groot-Atjeh, 2 dl., en (van het India Office) de blue books over de Indian Census van 1891 en het Tamil-werk "The Nālaḍiyār" door den Rev. G. U. Pope.

Plaatsing in de boekerij.

Van de hh.: Jhr. A. L. F. Th. van der Wijck en P. W. Filet te 's Gravenhage en Mr. J. Kalff te Paramaribo is bericht ontvangen dat zij de benoeming tot lid des Instituuts aanvaarden; van Jhr. E. T. M. van Alphen, dat hij het lidmaatschap opzegt; van de hh.: Raden Ismangoen Danoe Winoto (Magelang), W. Meijer Ranneft (Padang Sidempoean), G. J. Oudemans (naar Indië vertrekkende) en Ed. Jacobson (Pasir Klapa, Halte Tjibeber), mededeeling van veranderde adressen.

Notificatie. 
Door Dr. H. F. C. ten Kate is bij brief dd. 29 April 1894 het verzoek gedaan om subsidie voor de uitgaaf van eenige platen, behoorende bij eene in het Archiv für Ethnographie te plaatsen bijdrage.

$\mathrm{Na}$ gedachtenwisseling wordt besloten, aan de aanvraag geen gevolg te gegeven, vooral omdat de uitgaaf van het "International Archiv" reeds rechtstreeks door het Instituut gesteund wordt.

Van den heer Sidney H. Ray is ontvangen eene verhandeling over "the Makura Language of New Hebrides."

In handen van het Bestuurslid Niemann.

De $\mathrm{w}^{\mathrm{d}}$ Secretaris deelt mede dat - tengevolge der ziekte van Dr. Wijnmalen - de Abklatschen enz. uit Hadhramout, waarvan sprake is in de notulen der $344^{\text {ste }}$ Bestuursvergadering, nog waren blijven liggen. Hij heeft ze thans eerst aan Prof. de Goeje, en daarna overeenkomstig diens advies aan Dr. Ed. Glaser te Saaz in Bohemen gezonden.

Goedgekeurd.

Van den Commissaris, Dr. Brandes te Weltevreden, ziju ontvangen 2 brieven, van 21 Maart en 17 April 1894, houdende verschillende administratieve mededeelingen, toezending van een zichtwissel groot f 200.- en het verzoek om, voor zoover noodig, de van hem gevraagde jaarlijksche bijdrage voor het Koloniaal Verslag door het Bestuur te doen opmaken en rechtstreeks aan het Departement van Koloniën te doen indienen.

Notificatie.

In verband met deze correspondentie deelt de Voorzitter mede dat de vroeger ontvangen, nog onafgedane brieven van Commissarissen zijn nagegaan, doch dat enkele verschillen omtrent betaalde of niet betaalde contributiën enz. nog niet zijn opgehelderd. Daar de heer Zwager binnen weinige dagen hier te lande kan worden verwacht, wenscht de Voorzitter de geheele afdoening der brieven uit te stellen totdat de bedoelde verschillen mondeling zijn besproken en toegelicht.

Goedgekeurd.

Door den heer Poensen wordt, namens den heer Kern, aangeboden en ter plaatsing in de Bijdragen aanbevolen een opstel 
van Dr. H. H. Juynboll over "de mythe van den Berg Mandara in de Javaansche letterkunde."

Tot plaatsing wordt besloten.

De Voorzitter deelt mede, dat de verschillende uitgaven van het Instituut op de Internationale Tentoonstelling te Antwerpen worden geëxposeerd, en dat hij, onder nadere goedkeuring, namens het Instituut f 25.- heeft bijgedragen voor de bestrijding der door de Commissie te maken onkosten.

Goedgekeurd.

Door het lid Jhr. A. van der Wijck zijn voor het Instituutsarchief aangeboden eenige manuscripten, gevonden in den Kraton van Atjeh bij de verovering in 1874,

Onder dankbetuiging deponeeren.

De Vergadering wordt gesloten.

\section{2 $2^{\text {ste }}$ BESTUURSVERGADERING,} GEHOUDEN 23 JUNI 1894.

Aanwezig, de hh. der Kinderen (Voorzitter), Kern (OnderVoorzitter), Pijnacker Hordijk, Niemann, Poensen, J. H. de Groot (Penningmeester), Kielstra, ( $w^{\mathrm{d}}$ Secretaris).

Afwezig, met kennisgeving, de hh Canne, van der Lith, J. J. M. de Groot, van Limburg Stirum en Wijnmalen.

De notulen der Vergadering van 19 Mei jl. worden gelezen en goedgekeurd.

Ingekomen zijn :

1. Berichten van de hh. Mr. C. A. H. Barge te Curaçao, G. Lavino te Singapore, J. de Groot te Buitenzorg, O. Venema te Weltevreden en H. J. de Dompierre de Chaufepié te 's Gravenhage, dat zij het lidmaatschap des Instituuts aanvaarden; van den heer Mr. A. Heemskerk te 's Gravenhage en H. Helb te Weltevreden, 
dat zij met het einde van het loopende jaar van de ledenlijst wenschen afgevoerd te worden.

Notificatie.

2. Brief van den heer E. Lambrecht, Bibliothecaris van de Ecole Spéciale des Langues Orientales vivantes te Parijs dd. 6 Juni 1894, ten geleide der laatstelijk uitgegeven werken van deze instelling en met verzoek om inlichting of de werken van $\mathrm{D}^{\mathrm{r}}$ Groneman (Tjandi Prambanan) en van den heer De Nooy (Javaansche woordenlijst) aan de Bibliotheek der school zullen toegezonden, dan wel door haar aangekocht moeten worden.

Wordt besloten, de school een present-exemplaar van beide werken te doen toekomen.

3. Brief van Dr. E. Glaser te Saaz in Bohemen dd. 30 Mei 1894, houdende bericht omtrent de hem toegezonden Abklatschen enz. uit Hadhramout. Uit dit schrijven blijkt dat de stukken alle wetenschappelijke waarde missen.

De Secretaris deelt mede, het bericht van Dr. Glaser ter kennisneming te hebben toegezonden aan den Hoogleeraar de Goeje te Leiden.

Wordt besloten, den heer Glaser dank te zeggen voor zijne welwillende bemoeiingen.

4. Brief van den heer J. J. Reesse te Amsterdam dd. Mei 1894, ten geleide van het door hem vervaardigd manuscript over den Amsterdamschen suikerhandel vóór 1813.

De vergadering besluit, het stuk in handen te stellen van het lid Mr. N. P. van den Berg, met beleefd verzoek te dienen van advies, in hoever er voor het Instituut aanleiding zou kunnen bestaan de uitgaaf te steunen.

5. Brief van de Commissie van redactie van het International Archiv für Ethnographie te Leiden dd. 15 Mei 1894, houdende verzoek hare voorstellen tot oprichting van eene Internationale Maatschappij voor Ethnographie te steunen.

De Voorzitter deelt mede dat hij, in overleg met den Secretaris, het tot bedoeld einde toegezonden formulier den $23^{\text {n }}$ Mei jl. namens het Instituut geteekend heeft teruggezonden.

Goedgekeurd. 
6. Brief van den heer J. L. van der Toorn dd. 1 Mei 1894, gericht aan het bestuurslid Canne, houdende mededeeling dat de bij hem in depôt zijnde exemplaren van het Menangkabausch Woordenboek zijn uitverkocht en alzoo de toezending van nieuwen voorraad verlangd wordt, en verder dat de heer V. L. de Lannoy als lid van het Instituut wenscht toe te treden.

$\mathrm{Na}$ mededeeling van den Penningmeester, dat ten vorigen jare f 68 . - ontvangen is voor den verkoop van 8 exemplaren, zoodat de heer van der Toorn nog 17 exemplaren te verantwoorden heeft, deelt de $w^{\mathrm{d}}$ Secretaris mede dat hem den $16^{\mathrm{n}}$ Juni weder 25 exx. zijn toegezonden, met verzoek successievelijk de te innen gelden over te maken.

Goedgekeurd.

De heer De Lannoy te Fort de Kock wordt tot lid van het Instituut benoemd.

7. Circulaire $n^{\circ} 2$ van het $X^{\text {me }}$ Congrès International des Orientalistes te Genève, ad. Juni 1894, betreffende de deelneming aan het Congres.

Het bestuurslid Niemann, zich daartoe bereid verklarende, wordt benoemd tot vertegenwoordiger van het Instituut bij het Congres; hiervan zal aan het comité mededeeling worden gedaan.

8. Brief van den heer E. Nijland, directeur der Marnix-Stichting te Utrecht dd. 23 Mei 1894, houdende verzoek in overweging te nemen op het niet op den weg des Instituuts zoude kunnen liggen , de uitgaaf van goede platen voor het onderwijs, handelende over het volksleven van Ned. Indië, door het verleenen van eene subsidie te steunen.

$\mathrm{Na}$ gedachtenwisseling is de vergadering eenstemmig van meening, dat de uitgaaf van platen ten behoeve van het lager onderwijs in Nederland geheel valt buiten den werkkring van het Instituut; dat daarvoor veeleer eene maatschappij geroepen is als die "Tot Nut van 't Algemeen", die zich o. a. de bevordering van dat onderwijs ten doel stelt.

9. Brief van den heer H. A. de Nooy te Batavia dd. 10 Mei 1894, houdende eenige opmerkingen omtrent de door het Instituut bezorgde uitgaaf zijner Javaansche Woordenlijst, verzoek om het 
manuscript terug te ontvangen en tevens om toezending van het toekomend honorarium.

De Secretaris zal aan het eerste, de Penningmeester aan het laatste verzoek voldoen.

10. Brief van $D^{r}$. Brandes, Commissaris des Instituuts te Batavia, dd. 6 Mei 1894, waarbij een postwissel van f 1000.Ind. Ct. in mindering der voor 1893 verschuldigde contributien.

De Penningmeester deelt mede, dat hij den $20^{\text {n }}$ dezer de goede ontvangst heeft erkend.

Notificatie.

11. Brief van Jhr. Mr. J. K. W. Quarles van Ufford, houdende verzoek dat het Instituut zijne instemming betuige met de rekesten om het Rijks Ethnographisch Museum van Leiden naar den Haag over te brengen.

$\mathrm{Na}$ gedachtenwisseling wordt besloten aan dat verzoek niet te voldoen, aangezien het voor de Ethnographische wetenschap wel van veel belang is dat er een goed museum zij, maar niet of dit van Leiden naar den Haag wordt overgebracht.

12. Het bestuurslid Kern bespreekt, naar aanleiding van de, bij de dezer dagen verzonden "naamlijst der leden op 1 Juni 1894" gevoegde lijst der instellingen waarmede het Instituut door ruiling der uitgegeven werken in verbinding staat, de wenschelijkheid dien staat te herzien; onder bedoelde instellingen toch zijn er, wier edita niet de minste betrekking hebben op de Taal-, Landen Volkenkuude van Ned.-Indië en dus ook niet in onze bibliotheek thuis behooren; andere, van welke nooit iets ontvangen wordt.

De $w^{d}$ Secretaris stelt voor hem op te dragen, na onderzoek ter zake in de eerstvolgende vergadering een voorstel te doen.

Dienovereenkomstig wordt besloten.

De Voorzitter sluit de vergadering. 


\section{3 $3^{\text {ste }}$ BESTUURSVERGADERING, GEHOUDEN 22 SEPTEMBER 1894.}

Aanwezig de hh. der Kinderen (Voorzitter), Kern (Onder-Voorzitter), Canne, Pijnacker Hordijk, Niemann, Van der Lith, J. J. M. de Groot, Poensen, J. H. de Groot (Penningmeester) en Kielstra ( $w^{\mathrm{d}}$ Secretaris).

Afwezig, met kennisgeving, de hh. van Limburg Stirum en Wijnmalen.

De notulen der Vergadering van 23 Juni jl. worden gelezen en goedgekeurd.

Ingekomen zijn :

1. Brieven van de hh. Jhr. Mr. W. H. de Beaufort, C. H. C. Byvanck, E. J. Jellesma, H. C. Soeters en W. de Vogel, berichtende de aanneming van het lidmaatschap.

De $w^{\mathrm{d}}$ Secretaris deelt mede dat hij den 21 en Augustus jl. aan een zestal hh. in Indië, die op hunne benoeming nog niet hadden geantwoord, heeft geschreven.

Notificatie.

2. Brieven van de hh. J. A. van Dorsser, Dr. Jul. Jacobs, J. F. Niks, J. F. Scheltema, J. E. de Sturler, P. M. A. de Bruyn Prince, L. van Weelderen en het Buitenlandsch lid S. J. Hickson, houdende opgaaf van veranderd adres.

Notificatie.

3. Brief van den heer A. E. Kerkhoven, houdende bericht van het overlijden van het lid J. D. Harders; brieven van de hh. N. Graafland, G. P. Rouffaer, J. A. Schröder, M. C. E. Stakman, G. A. Hansen en L. J. van W lidmaatschap.

Notificatie.

4. Brief van den uitgever Martinus Nijhoff, met de afrekening over het jaar 1893.

Ter afdoening aan den Penningmeester. 
5. Voorstel van idem, om den handelsprijs der afzonderlijke overdrukken van $D^{r}$. N. Adriani's Sangireesche teksten te stellen op f 4.- en dien van Kruyt's Woordenlijst der Bareëtaal op f 2.-

Goedgekeurd.

6. enz.

7. Brieven van den Commissaris des Instituuts te Batavia dd. 27 Mei, 9 Juni, 25 Juni, 16 Augustus en 19 Augustus 1894, waarin

a. verschillende mededeelingen van administratieven aard, welke den Penningmeester aanleiding geven tot de verklaring dat het Instituut den Commissaris Dr. Brandes dank verschuldigd is voor den ijver en de zorg waarmede hij de financieele belangen der instelling heeft behartigd, en dat thans nagenoeg alle Indische contributiën over 1893 zijn geïnd.

b. mededeeling dat de heeren G. F. K. van Huls en Jhr. W. H. de Kock voor het lidmaatschap bedanken;

c. idem, dat de heer N. Chevalier te Fort de Kock als lid wenscht te worden ingeschreven;

d. bericht, dat het Instituut voortaan het Indisch weekblad van het Recht zal ontvangen in ruil voor zijne edita;

$e$ voorstel, om tot zijnen mede-commissaris te benoemen den heer B. Hoetink, tolk voor de Chineesche taal te Batavia.

Wordt besloten :

ad a. den heer Brandes den dank des bestuurs aan te bieden voor zijne zeer gewaardeerde medewerking om de administratie des Instituuts weder op geregelden voet te brengen;

ad b. notificatie;

ad c. den heer Chevalier te benoemen tot lid;

ad $d$. notificatie;

ad $e$. den heer Hoetink te benoemen tot tweeden Commissaris van het Instituut.

8. Brief van den Bibliothecaris der Ecole Speciale des langues Orientales vivantes te Parijs, dd. 28 Juni jl. houdende dankbetuiging voor de toezeuding der presentexemplaren van Tjandi Prambanan en de Nooy's woordenlijst.

Notificatie.

9. Brief van den heer H. Zondervan, te Bergen op Zoom, dd. 
25 Juni 1894, houdende verzoek om inlichting of het Instituut genegen zoude zijn de uitgaaf op zich te nemen of te bevorderen van eene studie over het eiland Bangka en zijne bewoners.

Wordt besloten te antwoorden dat het Bestuur gaarne, alvorens dienaangaande eenige beslissing te nemen, inzage zoude ontvangen van het manuscript.

10. Brief van Prof. Dr. R. Brandstetter te Luzern, dd. 14 Sept. 1894, houdende anbieding van een exemplaar der Geschichte von Hang Tuwah.

Door den $\mathrm{w}^{\mathrm{d}}$ Secretaris is voor die toezending bereids dank betuigd.

11. Brief van Dr. W. Caland te Breda dd. 5 Sept. 1894, waarbij ter opneming in de Bijdragen wordt aangeboden een opstel van zijne hand, getiteld: Der Gautamaçrāddhakalpa und Literatur, ein Beitrag zur Geschichte der Sāmavedaschulen.

Op voorstel van, den onder-Voorzitter, Prof. Kern, wordt tot de opneming besloten.

Het Bestuurslid, Prof. Niemann, brengt verslag uit over het in zijne handen gesteld opstel van den heer Sidney H. Ray. De slotsom van het verslag is, dat de plaatsing van het opstel in de Bijdragen niet kan worden aanbevolen.

De Vergadering, zich met dit advies vereenigende, besluit tot terugzending, onder dankbetuiging, aan den schrijver.

De $w^{d}$ Secretaris brengt, overeenkomstig de hem in de vorige Bestuursvergadering gegeven opdracht, de herziening ter sprake van de lijst der buitenlandsche instellingen, waarmede het Instituut door ruiling der uitgegeven werken in verbinding is.

Wordt besloten, van de lijst te royeeren de volgende instellingen, van welke niets ontvangen wordt:

Société Asiatique, te Parijs;

Société des études Japonaises, Chinoises, Tartares et IndoChinoises te Parijs;

Musée d'histoire naturelle, te Parijs;

Société de géographre de Lyon;

$$
\text { id. de Tours; }
$$

Société de géographie et d'archéologie de la province d'Oran; Real Academia de Ciencias de Lisboa; 
Königliche Academie der Wissenschaften, te München ;

Zeitschrift für wissenschaftliche Geographie, te Weimar;

Royal geographical Society te Londen;

Public Library of Victoria, te Melbourne, en

Royal Society of Victoria, te Melbourne.

Verder wordt besloten :

aan de Société d'ethnographie te Parijs aanvulling te verzoeken van de ontbrekende werken;

de Societa Geografica Italiana te Rome aan de toezending harer edita te herinneren;

de General-verwaltung der Königlichen Museen te Berlijn geregelde toezending harer uitgaven te vragen;

aan de Asiatic Society of Bengal, te Calcutta, hetzelfde verzoek te doen,

en eindelijk, eene poging aan te wenden tot aanknooping van betrekkingen, door ruiling der werken, met de Royal Society of New-South-Wales, te Sydney.

Door het bestuurslid Prof. Poensen wordt, namens Prof. Mr L. W. C. van den Berg, een afdruk aangeboden van zijn opstel: Le droit pénal de la Turquie.

Door het bestuurslid Prof. Dr. J. J. M. de Groot wordt ter tafel gebracht een aan hem gericht schrijven van den heer W. Roosegaarde Bisschop, werkzaam aan het India Office te Londen, waarin de wenschelijkheid wordt betoogd dat in Nederland afschriften aanwezig zijn van de voor de Koloniale geschiedenis belangrijke stukken, aanwezig in het India Office, over de jaren $1603-1830$.

Wordt besloten, ter zake een schrijven te richten tot Z. Exc. den Minister van Koloniën.

De $w^{\mathrm{d}}$ Secretaris brengt de wenschelijkheid ter sprake om, nu de catalogus van hèt Indisch Genootschap gereed is, tegelijkertijd ook een soortgelijken catalogus van het Instituut te doen uitgeven, waartoe de Secretaris des Genootschaps zijne welwillende hulp heeft toegezegd.

De Vergadering hecht aan het plan hare goedkeuring. Het bestuurslid Prof. de Groot wijst op de wenschelijkheid, aan het einde van den catalogus een alphabetische lijst op te nemen van de namen der schrijvers. 
Door den President wordt tot lid voorgedragen de heer A. A. Fokker, candidaat in de Oostersche letteren te Leiden; door den w $^{\text {d }}$ Secretaris, de heer P. H. van der Kemp, Directeur van het Departement van Onderwijs, Eeredienst en Nijverheid te Batavia. Beide heeren worden met algemeene stemmen tot lid aangenomen.

De heer Niemann geeft een kort verslag van het door hem als afgevaardigde van het Instituut bijgewoond Orientalisten-Congres te Genève, waaruit blijkt dat op genoemd congres geene onderwerpen zijn ter sprake gekomen welke vallen binnen den kring der studiën waarmede het Instituut zich bezig houdt.

De Vergadering wordt gesloten.

\section{$354^{\text {ste }}$ BESTUURSVERGADERING,} GEHOUDEN 20 OCTOBER 1894.

Aanwezig de hh. der Kinderen (Voorzitter), Kern (OnderVoorzitter), Canne, Pijnacker Hordijk, Niemann, van der Lith, Poensen, van Limburg Stirum, J. H. de Groot (Penningmeester) en Kielstra ( $w^{\mathrm{d}}$ Secretaris).

Afwezig, met kennisgeving, de hh. J. J. M. de Groot en Wijnmalen.

De notulen der vergadering van 22 September 1894 worden gelezen en goedgekeurd.

Ingekomen zijn :

$1^{\circ}$. Brief van den heer P. Kolff te Medan, houdende mededeeling dat hij de benoeming tot Instituutslid, in te gaan met heł jaar 1895, aanvaardt;

Brieven van de leden J. Knebel (Pamalang, Tegal), H. J. A. Raedt van Oldenbarnevelt (Breda), W. van Gelder (Probolinggo) 
en H. D. H. Bosboom (Weltevreden), houdende opgaaf van veranderd adres.

Notificatie.

2. Brief van Mevrouw E. J. H. Nijhoff-Cool, dd. 26 September jl., houdende bericht van het overlijden van het lid Martinus Nijhoff, uitgever van de werken des Instituuts.

Wordt besloten, Mevrouw Nijhoff de deelneming van het bestuur te betuigen.

$3^{\circ}$. Brief vau het lid M. J. C. M. Kolkman, tot opzegging van het lidmaatschap.

Notificatie.

$4^{\circ}$. Twee brieven dd. Sept. 1894 van de Nederlandsche Commissie bij de Wereldtentoonstelling te Antwerpen in 1894, mededeelende dat de Internationale Jury dier tentoonstelling aan het Instituut twee gouden medailles heeft toegekend.

Brief dd. 5 Oct. jl. van het bestuur der Indologische vereeniging te Delft, het Instituut met deze onderscheidingen geluk wenschende.

Notificatie.

$5^{\circ}$. Brief dd. 4 Oct. 1894 van de firma Martinus Nijhoff, ter mededeeling dat het $2^{\mathrm{e}}$ stuk (aanteekeningen) van Babad Tanats Djawi, uitgegeven door J. J. Meinsma, is uitverkocht.

$\mathrm{Na}$ gedachtenwisseling wordt het bestuurslid Poensen uitgenoodigd, in eene volgende vergadering te dienen van advies omtrent de wenschelijkheid van een herdruk.

$6^{\circ}$. Brief van den heer H. Zondervan, te Bergen op Zoom, dd 18 October 1894, houdende mededeeling dat zijne studie ove] Bangka zal verschijnen in de Indische Gids.

Notificatie.

7० Brief dd. 16 Oct. 1894 van den heer J. Boudewijnse, waarbi deze zich bereid verklaart den catalogus der Bibliotheek van he Instituut te bewerken, en de wenschelijkheid aantoont de catalog van Indisch Genootschap en Indisch Instituut bijeen te voegen Het bestuur vereenigt zich met de meening van den hee Boudewijnse. 
Het bestuurslid Kern brengt ter tafel een door den zendeling van Baarda samengesteld woordenboek over de Galelareesche taal.

In handen gesteld van de hh. Kern en Niemann om advies aangaande de nitgaaf vanwege het Instituut.

Het bestuurslid Canne wijst op de wenschelijkheid, dat de Bibliotheek ook in de ochtenduren voor de leden toegankelijk zij.

Den Secretaris wordt opgedragen, omtrent dit onderwerp in de volgende vergadering te rapporteeren.

De Vergadering wordt gesloten. 


\section{$355^{\mathrm{e}}$ BESTUURSVERGADERING,}

ZATERDAG 17 NOVEMBER 1894.

Aanwezig de HH. der Kinderen (Voorzitter), Kern (Ondervoorzitter), Poensen, J. J. M. de Groot, Canne, van der Lith, Pijnacker Hordijk, Niemann, J. H. de Groot (penningmeester) en Kielstra (wd. Secretaris).

Afwezig, met kennisgeving, de HH. van Limburg Stirum en Wijnmalen.

De notulen der vergadering van 20 October 1894 worden gelezen en goedgekeurd.

\section{Ingekomen zijn :}

$1^{\circ}$. Bericht van den heer E. A. Rovers dat hij met ingang van het jaar 1894, van den heer J. Mullemeister dat hij met ingang van het jaar 1895 het lidmaatschap aanvaardt;

$2^{\circ}$. Bericht van Mevrouw de Wed. Klinkhamer betreffende het overlijden, op 5 November j.l. van het lid mr. F. A. Klinkhamer;

$3^{\circ}$ Bericht van de HH. G. H. Betz, G. F. de Bruyn Kops, A. Mellink en H. A. de Groot, die met het einde des jaars hun lidmaatschap wensehen te doen eindigen;

$4^{\circ}$. Mededeeling van den heer W. J. M. Michielsen, omtrent zijn tegenwoordig adres.

Notificatie.

5. Bericht dat de Berliner Gesellschaft für Anthropologie, Ethnologie und Urgeschichte heden haar 25-jarig bestaan viert.

De Voorzitter deelt mede dat aan de Gesellschaft de gelukwensehen van het bestuur worden overgebracht door het correspondeerend lid J. D. E. Schmeltz.

$6^{\circ}$. Brief van den heer J. Boudewijnse, dd. 11 dezer, houdende verzoek bij de samenstelling van den catalogus der boekerij, wat het linguistisch gedeelte betreft, ter zijde te worden gestaan door deskundigen op dat gebied. 
De HH. Niemann en Poensen verklaren zich tot het verleenen der noodige hulp bereid; hiervan zal den heer Boudewijnse mededeeling worden gedaan.

7\%. Brief van den Minister van Koloniën d.d. 7 Nov. 1894 La A 1 $\mathrm{n}^{\circ} 62$, waarbij wordt medegedeeld dat de Britsche Regeering machtiging heeft verleend tot het doen afschrijven van de in het India Office te Londen berustende, voor onze koloniale geschiedenis belangrijke archiefstukken over het tijdperk 1603-1830; dat het Instituutsbestuur wordt uitgenoodigd, in overleg met den Algemeenen Rijksarchivaris voor het copieeren zorg te dragen, en dat daartoe over hoogstens f 1500.- 's jaars ten laste der koloniale begrooting kan worden beschikt.

De wd. Secretaris geeft verslag van de door hem met den Algemeenen Rijksarchivaris gevoerde correspondentie en bespreking, en stelt voor het door hem ontworpen schrijven aan den heer W. Roosegaarde Bisschop, werkzaam aan het India Office te Londen, goed te keuren als behelzende de voorloopig aan dien heer te verstrekken instructiën.

De vergadering vereenigt zich met dit voorstel, en verklaart de welwillendheid van den heer Roosegaarde Bisschop om namens het Instituut de leiding der zaak te Londen op zich te nemen, op hoogen prijs te stellen.

80. Brief van de firma E. J. Brill te Leiden, houdende anbieding van 25 exx. van Prof. Martin's Reisen in den Molukken, met verzoek om mededeeling wanneer de toegezegde subsidie kan worden ontvangen.

De Voorzitter deelt mede, dat het schrijven der firma door hem na overleg met den penningmeester is beantwoord, en dat de 25 exx. aan den Minister van Koloniën zijn aangeboden met verzoek, de door de Regeering toegezegde subsidie te willen beschikbaar stellen.

Het bestuurslid Niemann brengt verslag uit omtrent het in zijne handen gesteld Galelareesch-Nederlandsch Woordenboek door den heer van Baarda. Zijn oordeel luidt hoogst gunstig, zoodat hij in overweging geeft zoodra mogelijk tot de uitgaaf over te gaan.

De heer Kern vereenigt zich met dit advies.

Besloten wordt, de uitgaaf, waarvan de kosten op cc. f 1200.- 
zijn geraamd, te ondernemen; aan den Minister van Koloniën subsidie voor die uitgaaf te vragen, en op de a. s. Algemeene Vergadering voor te stellen, op dit werk art. $13,2^{\mathrm{e}}$ al. van het Reglement van toepassing te verklaren.

De heer Poensen stelt voor, thans niet over te gaan tot den herdruk van het $2^{\mathrm{e}}$ stuk der Babad Tanah Djawi, maar later, wanneer het $1^{\mathrm{e}}$ stuk is uitverkocht, aan den herdruk hiervan de noodige (herziene) aanteekeningen toe te voegen.

Dienovereenkomstig wordt besloten.

De wd. Secretaris stelt voor, aan te vangen met 1 Januari van het volgende jaar, de bibliotheek open te stellen van 10-12 en 2 -4 uur op alle werkdagen, behalve des Donderdags, - onder mededeeling dat het Bestuur van het Indisch Genootschap zich met deze wijziging van art. 4 van het reglement op de bibliotheken kan vereenigen.

Dienovereenkomstig wordt besloten.

De wd. Secretaris draagt voor tot lid de heer H. Verleye, $1^{\text {e }}$ commies bij het Departement van Binnenlandsch Bestuur te Weltevreden.

Met acclamatie wordt de heer Verleye benoemd.

De heer Niemann deelt mede dat hem door den heer C. M. Pleyte Wzn. ten behoeve van de Bijdragen is toegezonden de vertaling van een Bataksch handschrift op boomschors, in de Leidsche bibliotheek aanwezig. Dit stuk bevat historische mededeelingen omtrent vroegere Mandaïlingsche hoofden, en komt in hoofdzaak overeen met de ter zake verstrekte mededeelingen in Willer's Verzameling van Battasche wetten en instellingen in Mandaïling en Pertibi (T. v. N. I. $8^{e}$ jaargang (1846), $2^{e}$ deel bl. 145 en vlg.).

Om deze reden meent de heer Niemann de plaatsing van bovenbedoelde vertaling in de Bijdragen niet te kunnen aanraden.

Dienovereenkomstig wordt besloten.

De heer Poensen deelt mede dat door hem uit de papieren, nagelaten door den onlangs overleden zendeling Wijngaarden, is samengesteld eeue Savoeneesch-Nederlandsche woordenlijst, en 
vraagt mededeeling in hoever het Instituut de uitgaaf van die woordenlijst op zich zou kunnen nemen.

$\mathrm{Na}$ beraadslaging, waaraan de H.H. Niemann en Kern deel nemen, wordt in beginsel besloten tot de publicatie.

Ter Algemeene Vergadering zal worden voorgesteld, ook op deze uitgaaf het $2^{\mathrm{e}}$ lid van art. 13 van het Reglement toe te passen.

De heer Niemann stelt voor, te benoemen tot buitenlandsch lid de heer Richard Andree, Redacteur van de Globns, te Brunswijk.

Met algemeene stemmen wordt deze benoeming goedgekeurd.

Niets meer te behandelen zijnde, sluit de Voorzitter de Vergadering.

\section{$356^{\circ}$ BESTUURSVERGADERING,}

\section{ZATERDAG 15 DECEMBER 1894 .}

Aanwezig de. HH. der Kinderen (Voorzitter), Kern (Ondervoorzitter), Pijnacker Hordijk, Canne, J. J. M. de Groot, Poensen, Niemann en Kielstra (wd. Secretaris).

Afwezig, met kennisgeving, de HH. van der Lith, van Limburg Stirum, J. H. de Groot (Penningmeester) en Wijnmalen.

De notulen der vergadering van 17 November 1894 worden gelezen en goedgekeurd.

Ingekomen zijn :

$1^{\circ}$. Bericht van Dr. Richard Andree, waarbij hij zijne benoeming tot buitenlandsch lid aanneemt.

$2^{\circ}$. Bericht van de heeren J. Boers die met ingang van het jaar 1895 , en H. P. J. van den Berg die met ingang van het jaar 1894 het lidmaatschap aanneemt;

3。. Bericht van Dr. W. Burck, waaruit blijkt dat hij bij vergissing van de ledenlijst is afgevoerd; 
4\%. Bericht van de HH. Montijn en Wunderly tot opgaaf van veranderd adres;

5. Bericht van de HH. O. A. de Munnick, F. L. K. Storm van 's Gravesande, N. Graafland, Mr. H. de Stuers en S. Stibbe tot opzegging van het lidmaatschap, en bericht van het overlijden van het lid Mr. J. C. J. van der Schalk.

Notificatie.

Op voordracht van den wd. Secretaris worden tot lid benoemd de HH. A. K. Derx, adsistent-resident te Siboga, en C. A. de Munnick, adsp.-controleur te Djoewana (Japara).

Door de.HH. Joh. Snelleman en J. F. Niermeijer is bij schrijven van 21 Nov. jl. het verzoek gedaan, bij de uitgaaf van den tweeden druk van Veth's Java een viertal photogrammen uit Tjandi Prambanan te mogen reproduceeren.

Geene bedenking.

Van den Minister van Koloniën is onder dagteekening van 26 November La. A ] $\mathrm{n}^{\circ} 29$ bericht ontvangen dat er geene gelegenheid bestaat om van Regeeringswege de voorgenomen uitgaaf van een Galelareesch Woordenboek te subsidieeren.

Notificatie.

De wd. Secretaris deelt mede dat de eerste helft der subsidie voor Prof. Martins werk van het Departement van Koloniën is ontvangen en aan de firma Brill zal worden uitbetaald.

Notificatie.

Van Die Gesellschaft für Anthropologie, Ethnologie und Urgeschichte is dd. 28 November 1894 eene dankbetuiging ontvangen voor de gelukwenschen, namens het Instituut door den heer Schmeltz aangeboden.

Notificatie.

Namens den Penningmeester, die door ongesteldheid verhinderd is aanwezig te zijn, wordt door den wd. Secretaris de begrooting voor het aanstaande dienstjaar ter tafel gebracht.

Zij wordt, na eenige toelichting, zonder discussie goedgekeurd.

De vergadering wordt gesloten. 


\section{BESTUURSVERGADERING,}

ZATERDAG 19 JANUARI 1895.

Aanwezig de HH. der Kinderen (Voorzitter), Kern (Ondervoorzitter), Canne, Poensen, van der Lith, Niemann, Pijnacker Hordijk, J. H. de Groot (Penningmeester) en Kielstra (wd. Secretaris).

Afwezig, met kennisgeving, de HH. van Limburg Stirum en J. J. M. de Groot.

De notulen der vorige vergadering worden gelezen en goedgekeurd.

De Voorzitter brengt - na den wensch te hebben uitgesproken dat het jaar 1895 getuige zal zijn van eene krachtige werkzaamheid en van voortdurenden bloei van het Instituut - in herinnering het afsterven op den $14^{\text {den }}$ dezer, na een langdurig en smartelijk lijden, van Dr. T. C. L. Wijnmalen, die gedurende een reeks van jaren, als bestuurslid en secretaris, zijne beste krachten aan het Instituut heeft gewijd. Terwijl sinds lang eene sleepende ziekte zijn lichaam en zijn geest sloopte, heeft hij zoolang het hem eenigszins mogelijk was met de meeste energie getracht zijne functiën te vervullen; onder de bestuursleden zal de nagedachtenis van hem, die Indië en onze Instelling lief had, in aangename herinnering blijven.

Vanwege het Instituut hebben Voorzitter, Penningmeester en wd. Secretaris, daartoe door de familie uitgenoodigd, den lijkstoet gevolgd en den overledene de laatste eer bewezen; de Voorzitter heeft, ook namens het Indisch Genootschap, bij de ter aarde bestelling een kort woord van hulde en sympathie gesproken.

Tot secretaris van het Instituut wordt benoemd het bestuurslid E. B. Kielstra, die zich bereid verklaart de benoeming te aanvaarden.

Ingekomen zijn de volgende stukken:

1. Bericht van den heer Mr. C. B. Nederburgh te Buitenzorg, dat hij bereid is het hem aangeboden lidmaatschap te aanvaarden.

2. Bericht van de HH. F. H. Göbel, J. A. van Dorsser, H. 
C. Klinkert Sr., E. Douwes Dekker, J. W. Stemfoort, E. A. Staal van Holstein van Vloten en J. Walland, dat zij met ingang van het jaar 1895 voor het lidmaatschap bedanken.

3. Bericht van de redactie van het Ned. Zendingstijdschrift en van het buitenlandsch lid Dr. Pardo de Tavera, betreffende verandering van hun adres.

4. Dankbetuiging van Prof. P. J. Veth voor de medewerking van het Instituut aan den hem op 2 Dec. jl. aangeboden feestbundel.

5. Dankbetuiging van de HH. Snelleman en Niermeyer voor de in de vorige vergadering op hun verzoek genomen beslissing.

Notificatie.

6. Bericht van den Secretaris der Asiatic Society of Bengal dat deze hare achterstallige uitgaven aan het adres van het Instituut heeft verzonden en wederkeerig toezending verzoekt van eenige ontbrekende afleveringen der Instituutswerken.

De Secretaris deelt mede dat bedoelde uitgaven in behoorlijke orde zijn ontvangen; hem wordt opgedragen, voor zooveel mogelijk, aan het verzoek te voldoen.

7. Uitnoodiging van de Anthropologische Gesellschaft te Weenen, ter bijwoning van de op 12 Febr. a. s. te houden feestviering van haar 25-jarig bestaan.

Wordt besloten, haar een brief van gelukwensch te doen toekomen.

8. Mededeeling van Mevr. Wijnmalen omtrent het overlijden van haren echtgenoot.

Wordt besloten, deze mededeeling met een brief van rouwbeklag te beantwoorden.

9. Brief van den heer Roosegaarde Bisschop te Londen, dd. 21 December jl., waarin deze mededeelt dat men hem aan het India Office nog geene gelegenheid heeft gegeven ten behoeve van het Instituut werkzaam te zijn, aangezien het officieele bericht, dat hij daartoe werd aangewezen, nog niet was ontvangen.

De President deelt mede, dat onmiddellijk na ontvangst van dit schrijven de Minister van Koloniën is uitgenoodigd, tot legitimatie van den heer Roosegaarde Bisschop het noodige te willen 
verrichten, en dat door ZExc. met de meeste bereidwilligheid aan dit verzoek is voldaan.

De President deelt mede dat van de firma Brill is ontvangen een gebonden present-exemplaar van de Reisen in den Molukken etc. van Prof. Martin. Aan de firma is daarvoor dank betuigd, en op voorstel van den president wordt besloten aan Prof. Martin den dank van het Instituut aan te bieden voor de wijze waarop hij zijne taak heeft volbracht.

Door het lid Dr. L. W. G. de Roo zijn, namens den heer L. J. J. Michielsen, aan de Bibliotheek van het Instituut toegegezonden de verslagen van de Kamer van Koophandel en Nijverheid te Batavia over de jaren 1864-1869.

Onder dankbetuiging deponeeren.

Door den heer C. A. van Troostenburg de Bruyn, predikant te Heeze bij Eindhoven is, bij schrijven van 11 Januari 1895 , eene subsidie gevraagd voor de uitgaaf eener biographie van krankbezoekers en ziekentroosters welke in Ned. Indië zijn werkzaam geweest.

$\mathrm{Na}$ beraadslaging wordt besloten, den heer de Bruyn mede te deelen dat het bestuur bereid is om, wanneer het werk verschenen zal zijn, daarvan een exemplaar te koopen voor vijftig gulden.

De President deelt mede dat alles wat vanwege het Instituut naar de Antwerpsche tentoonstelling is ingezonden, in de beste orde is terugontvangen, en stelt voor, het lid Mr. A. J. E. A. Bik, die met zooveel ijver en belangstelling voor het Instituut is opgetreden, dank te betuigen.

Conform besloten.

De Secretaris deelt mede dat in de laatste jaren herhaaldelijk boeken uit de Bibliotheek worden uitgeleend aan niet-leden. In overeenstemming met zijnen ambtgenoot van het Indisch Genootschap is hij van oordeel, dat zulks niet geoorloofd is, aangezien het ten nadeele kan strekken van de leden, en ook niet wel in overeenstemming met art. 7 van het Reglement. Doch alvorens ten deze bevelen te geven, vraagt hij de meening van het bestuur.

Uit de ter zake gevoerde gedachtenwisseling blijkt, dat alle bestuursleden zijn gevoelen deelen. 
De Penningmeester brengt ter tafel zijne verantwoording over het jaar 1894. Zij wordt staande de vergadering nagezien door de bestuursleden Canne en Poensen, die haar in volkomen orde bevinden.

Tot leden der Commissie, bedoeld in art. 4, laatste alinea, van het huishoudelijk reglement, worden benoemd de HH F. S. A. de Clereq en D. A. Hooijer.

De ondervoorzitter draagt voor tot buitenlandsch lid Sr. D. W. E. Retana te Madrid.

Met algemeene stemmen wordt deze voordracht goedgekeurd.

De vergadering wordt gesloten.

\section{BESTUURSVERGADERING,}

\section{Zaterdag 16 FEbrUari 1895.}

Aanwezig de HH. der Kinderen (Voorzitter), Canne, Poensen, van der Lith, Niemann, J. J. M. de Groot, van Limburg Stirum, J. H. de Groot (Penningmeester) en Kielstra (Secretaris).

De notulen der vorige vergadering worden gelezen en goedgekeurd.

De Voorzitter spreekt een hartelijk woord van gelukwensch tot het bestuurslid Niemann, naar aanleiding van diens benoeming, door den Senaat der Leidsche Universiteit, tot doctor honoris causa in de faculteit der letteren en wijsbegeerte; eene onderscheiding, waarin alle bestuursleden zich ten zeerste verheugen.

Ingekomen zijn de volgende stukken:

1. Berichten van de leden P. J. van Santen, C. W. J. Wenneker, L. Knappert, J. H. J. Sigal, F. E. Luitjes en W. J. Derx, omtrent hun veranderd adres.

2. Bericht van het overlijden van het lid F. A. Vriese.

3. Bericht van het Buitenlandsch lid W. E. Retana te Madrid, dat hij de benoeming als zoodanig gaarne aanvaardt. 
4. Mededeeling van de leden E. Fokker en H. L. M. Luden, dat zij hun lidmaatschap wenschen te doen eindigen.

Notificatie; in verband met art. 6 van het Reglement wordt laatstbedoelde mededeeling beschouwd als van toepassing bij het het einde van het loopende jaar.

5. Brief van den heer J. Walland te 's Gravenhage, dd. 11 Januari 1895, houdende aanbieding van een exemplaar der Code of laws established by the Pangerans Court at Fort Marlborough, 1817, welk werk hoogst zeldzaam is. (Zie Mr. L. W. C. van den Berg's Rechtsbronnen, Bijdragen 1894, IX $^{\mathrm{e}}$ deel bl. 200, noot).

Den heer Walland is voor dit geschenk bereids dank betuigd.

6. Brief van 28 Januari 1895 van den heer C. Honigh, leeraarbibliothecaris aan de Rijkslandbouwschool te Wageningen, houdende verzoek om toezending der uitgaven van het Instituut, desverlangd in ruil met het Zijdschrift voor Landbouwkunde en het Verslag van den Landbouw in Nederland.

Aangezien deze werken minder op hunne plaats zijn in de Bibliotheek van het Instituut, wordt besloten aan de Bibliotheek der Rijkslandbouwschool een exemplaar der vanwege het Instituut uitgegeven werken aan te bieden, zonder voorwaarde van reciprociteit.

7. Brief van den Commissaris Dr. Brandes, dd. 31 Dec. 1894, houdende o. a. afrekening over 1894 .

Notificatie.

8. Brief van de Kon. Akademie der Wissenschaften te München dd. 5 Februari 1895 , waarin - na aanbieding van verontschuldigingen voor de niet-toezending der door haar uitgegeven werken en toezegging dat deze alsnog zullen worden gezonden - wordt voorgesteld de gestaakte ruiling der wederzijdsche uitgaven te hervatten.

Dit voorstel wordt gaarne aangenomen.

De Secretaris brengt ter sprake de verzekering tegen brandschade der bibliotheken van het Instituut en het Indiseh Genootschap.

Aangezien die bibliotheken niet feitelijk gescheiden zijn, schijnt het wenschelijk ze te zamen en wel voor gemeenschappelijke rekening bij ééne maatschappij te verzekeren. 
Wordt besloten, overeenkomstig dit voorstel de gecombineerde bibliotheek te verzekeren voor eene waarde van dertig duizend gulden, waarvan $\frac{2}{3}$ voor het Instituut, $\frac{1}{3}$ voor het Indisch Genootschap.

De penningmeester wordt uitgenoodigd, hiervoor in overleg met den penningmeester van het Genootschap het noodige te verrichten.

De Secretaris brengt ter tafel een door hem samengesteld concept van het in de a. s. Algemeene Vergadering uit te brengen jaarverslag over 1894, hetwelk met eene kleine wijziging wordt goedgekeurd.

Het bestuurslid Niemann brengt ook namens het bestuurslid van der Lith verslag uit omtrent de in Mei 1894 door het lid Jhr. A. L. F. Tн. van der Wijck aangeboden, in 1874 in den kraton te Atjeh gevonden boeken.

Uit het verslag blijkt dat die boeken niet de minste waarde bezitten.

Wordt besloten, den heer van der Wijck hiervan mededeeling te doen.

$\mathrm{Na}$ eenige bespreking worden de volgende drietallen opgemaakt, welke, ter vervulling der aanstaande vacatures, aan de algemeene vergadering zullen worden aangeboden.

I. Vacature der Kinderen (aftreding 1899): Dr. J. Spanjaard, Mr. J. de Louter, Jhr. Mr. H. van der Wijck.

II. Vacature Wijnmalen (aftreding 1896): Mr. L. W. C. van den Berg, Dr. G. Schlegel, Dr. A. C. Vreede.

III. Vacature Kielstra (aftreding 1899): E. B. Kielstra, A. J. Spaan, Jhr. Mr. W. Elout van Soeterwoude.

IV. Vacature Niemann (aftreding 1899): Dr. K. Martin, Jhr. Mr. J. K. W. Quarles van Ufford, R. C. Kroesen.

Tot leden van het Instituut worden benoemd de heeren:

F. H. P. van Alphen, lid van de Eerste Kamer der StatenGeneraal te Rotterdam.

Mr. T. M. C. Asser, lid van den Raad van State te 's Gravenhage.

J. C. C. den Beer Poortugael, lid van den Raad van State te 's Gravenhage. 
Mr. E. H. J. M. M. van Zinnicq Bergman, lid van de Eerste Kamer der Staten-Generaal te 's Hertogenbosch.

Dr. P. J. Blok, Hoogleeraar te Leiden.

Jhr. A. W. van Borssele, lid van de Tweede Kamer der StatenGeneraal, te Bennekom.

Mr. J. P. van Bosse, te 's Gravenhage.

A. Bouman, lid van de Tweede Kamer der Staten-Generaal, te Leeuwarden.

J. E. O. A. A. Graaf van Bylandt van Benthorn, te 's Gravenhage.

J. F. Haver Droeze, Consul-Generaal te 's Gravenhage.

Jhr. Mr. W. A. R. Engelen te 's Gravenhage.

J. Baron Fagel, Huize Avegoor, te Ellecom bij Dieren.

L. W. C. Gerlach, gep ${ }^{d}$. generaal-majoor te 's Gravenhage.

Jhr. D. de Graeff, oud minister-resident te 's Gravenhage.

K. J. G. Baron van Hardenbroek van Bergambacht, te "s Gravenhage.

Mr. Th. Heemskerk, Jid van de Tweede Kamer der Staten-Generaal te Amsterdam.

Mr. P. C. J. Hennequin, id. te Aardenburg.

Dr. C. C. Hesseling, privaat docent te Leiden.

Mr. H. F. Hesselink van Suchtelen, lid van de T'weede Kamer der Staten-Generaal te Wageningen.

Mr. J. C. Th. Heyligers, hoogleeraar te Delft.

G. B. 't Hooft, lid van de Tweede Kamer der St.ten-Generaal te Haarlemmermeer.

Mr. S. van Houten, Minister van Binnenlandsche zaken te 's Gravenhage.

W. M. Houwing, lid van de Tweede Kamer der Staten-Generaal te Havelte.

Mr. W. van der Kaay, Minister van Justitie te 's Gravenhage.

Mr. Ph. Kleyntjes, advocaat te Amsterdam.

F. M. Knobel, Consul-Generaal, minister-resident te Teheran.

A. Knijff Hz., lid van de Tweede Kamer der Staten-Generaal te Rietveld.

Mr. H. van Lier, lid van de Eerste Kamer der Staten-Generaal te Assen.

J. A. van der Loeff te 's Gravenhage.

Mr. A. Loudon, referendaris aan het Departement van Koloniën te 's Gravenhage.

L. H. A. Magnée, lid van de Eerste Kamer der Staten-Generaal te Horn. 
W. Merckelbach, idem te Breda.

Dr. S. A. Naber, Hoogleeraair te Amsterdam.

Mr. A. E. J. Nijsingh, lid van de Eerste Kamer der StatenGeneraal, te Meppel.

Mr. C. F. Pahud de Mortanges, adj.-commies bij het Dep. van Koloniën te 's Gravenhage.

M. J. H. Plantenga, directeur der Hoogere Krijgsschool te 's Gravenhage.

W. J. H. Prinzen, lid van de Eerste Kamer der Staten-Generaal te Helmond.

Jhr. Mr. D. Roëll, te 's-Gravenhage.

J. H. Romswinckel, gep'. generaal-majoor te 's Gravenhage.

Jhr. S. M. S. de Ranitz, Secretaris van H. M. de KoninginRegentes te 's Gravenhage.

Dr. P. H. Roessingh, lid van de Tweede Kamer der StatenGeneraal, te Leiden.

Mr. L. H. Ruyssenaers, minister-resident, chef van het kabinet van den Minister van Buitenl. Zaken te 's Gravenhage.

Mr. A. M. Sassen, lid van de Eerste Kamer der Staten-Generaal, te Breda.

Mr. F. D. Graaf Schimmelpenninck, lid van de Tweede Kamer der Staten-Generaal te Amersfoort.

A. Baron Schimmelpenninck van der Oye van de Poll en Nyenbeek, Commissaris der Koningin te Utrecht.

$\mathrm{Ph}$. W. van der Sleijden, Minister van Waterstaat, Handel en Nijverheid te 's Gravenhage.

Mr. E. A. Smidt, lid van de Tweede Kamer der Staten-Generaal te Utrecht.

Jhr. H. Smissaert te 's Gravenhage.

A. Smit, lid van de Tweede Kamer der Staten-Generaal te Rotterdam.

Mr. P. J. A. Smitz, lid van de Eerste Kamer der Staten-Generaal te Eindhoven.

C. D. H. Schneider, Minister van Oorlog te 's Gravenhage.

Mr. H. A. Nebbens Sterling, lid van de Eerste Kamer der Staten-Generaal te Dordrecht.

C. T. Stork, idem te Oldenzaal.

P.J.Truyen, lid van de Tweede Kamer der Staten-Generaal te Meijel.

Jhr. Mr. J. B. A. J. M. Verheyen, Lid van de Eerste Kamer der Staten-Generaal te 's Hertogenbosch. 
Mr. F. A. H. Weckherlin te 's Gravenhage.

L. Wessels, oud-resident te 's Gravenhage.

Mr. J. J. Willinge, lid van de Tweede Kamer der StatenGeneraal te Assen.

Jhr. H. M. van der Wijck, Minister van Marine te 's Gravenhage.

H. Zondervan, leeraar Middelbaar Onderwijs te Bergen op Zoom.

J. A. Ament, resident van Kadoe te Magelang.

P. C. Arends, id. van Madoera te Pamakassan.

C. G. van Baerle id. van Kediri te Kediri.

R. C. Bakhuijzen van den Brink, directeur van financiën te Weltevreden.

J. J. Bischoff, resident van Pekalongan.

J. H. W. Graaf van den Bosch, id. van Cheribon.

Mr. J. M. Brooshooft, president van den Raad van Justitie te Soerabaja.

H. M. La Chapelle, secretaris van den Raad van Ned. Indie, te Weltevreden.

Mr. H. K. J. van Deinse, id. bij het Departement van Justitie te Weltevreden.

J. van Delden, chef van de firma Reynst en Vinju te Batavia.

Mr. H. van Dissel, vice-president van het Hoog-Gerechtshof te Weltevreden.

B. W. F. Fokker, controleur der afdeeling Karimon (res. Riouw).

F. de Greve, referendaris ter Algemeene Secretarie te Buitenzorg.

Mr. J. J. F. van Hamel, raadsheer bij het Hoog-Gerechtshof te Weltevreden.

C. J. Hasselman, controleur $\mathrm{l}^{\mathrm{e}} \mathrm{kl}$. te Buitenzorg.

Mr. C. W. Kist, resident der Preanger-Regentschappen te Bandong.

A. M. Landveld, controleur $2^{\mathrm{e}} \mathrm{kl}$. te Segeri (Celebes).

J. H. Liefrinck, wd. adsistent-resident op Lombok.

P. J. F. Louw, kapitein der infanterie te Weltevreden.

Mr. G. H. Lowe, vice-president van het Hoog-Gerechtshof te Weltevreden.

N. H. van Maren, referendaris ter Algemeene Secretarie te Buitenzorg.

H. J. Monod de Froideville, resident van Bangka, te Muntok.

J. J. K. de Moulin, kolonel, chef van den Generalen Staf te Weltevreden. 
Mr. J. C. Mulock Houwer, procureur-generaal bij het HoogGerechtshof te Weltevreden.

A. van der Gon Netscher, resident van Bagelen, te Poerworedjo.

J. H. B. Oomen, adsistent-resident tè Batavia.

C. E. G. Ottenhoff, resident van Banjoemas.

Mr. J. Paulus, referendaris ter Algemeene Secretarie te Buitenzorg.

D. F. W. van Rees, idem.

R. van Romunde, adsistent-resident van Kendal (Samarang).

A. Salmon, resident van Pasoeroean.

J. J. van Santen, id. van Krawang te Poerwakarta.

M. Segov, generaal-majoor te Samarang.

Mr. A. Stibbe, directeur van Justitie te Weltevreden.

A. Suermondt, referendaris ter Algemeene Secretarie, Buitenzorg. Jhr. J. G. von Schmidt auf Altenstadt, resident van Batavia.

L. Swart, kolonel op Lombok.

W. H. S. van Waning, resident van Tegal.

Mr. G. D. Willinck, advocaat te Batavia.

W. H. Wijnmalen, referendaris ter Algemeene Secretarie te Buitenzorg.

H. P. Willemstijn, kapitein van den Generalen Staf te Weltevreden.

De vergadering wordt gesloten. 


\section{JAARVERSLAG OVER 1894.}

Het Bestuur bestond in het afgeloopen jaar uit de HH.: Mr. T. H. der Kinderen (voorzitter), Prof. G. K. Niemann, E. B. Kielstra; Prof. Dr. H. Kern (ondervoorzitter), J. H. de Groot (penningmeester), Dr. T. C. L. Wijnmalen (secretaris), Mr. O. J. H. Graaf van Limburg Stirum, Prof. C. Poensen, Prof. Dr. J. J. M. de Groot, Mr. C. Pijnacker Hordijk, Prof. Mr. P. A. van der Lith en H. D. Canne.

Van deze bestuursleden treden thans de drie eerstgenoemden af.

De secretaris, Dr. Wijnmalen, werd bij voortduring door zware ziekte verhinderd, zijne functiën te vervullen; in zijne plaats nam het bestuurslid Kielstra het secretariaat waar.

Tot ons groot leedwezen moeten wij hier vermelden, dat de heer Wijnmalen den 14, ${ }^{\text {en }}$ Januari jl. ons door den dood werd ontrukt. Hij had gedurende bijna een kwart eeuw, als bestuurslid en secretaris, medegewerkt tot den bloei van onze Instelling, die hem lief was; veel heeft deze aan zijne toewijding en aan zijnen ijver te te danken, en het is waarlijk geen ijdele plichtspleging, indien wij het vertrouwen uitspreken dat bij onze leden de herinnering aan Dr. Wijnmalen levendig zal blijven.

In zijne plaats werd, in de bestuursvergadering van 19 Januari jl., tot secretaris benoemd de heer Kielstra.

Tot ons genoegen kunnen wij constateeren dat het aantal leden in 1894 eenigszins toenam: op 1 Januari van dat jaar bedroeg het 536, op ulto December 548. Uitbreiding van het ledental blijft echter steeds gewenscht, met het oog op den omvangrijken werkkring van het Instituut.

Tot buitenlandsch lid werden benoemd Dr. Pardo de Tavera, thans te Manilla, en Dr. Richard Andree te Brunswijk.

Ter vervanging van den heer Zwager, wiens vertrek uit Indië reeds in het vorig verslag werd vermeld, werd, op voorstel van onzen Commissaris Dr. J. Brandes, tot mede-commissaris te Batavia aangesteld de heer B. Hoetink.

Voor de wijze, waarop de heer Brandes de belangen van het Instituut in Indië behartigde, is ons bestuur hem in hooge mate erkentelijk. 
Omtrent de bijzonderheden onzer werkzaamheden nemen wij de vrijheid, naar de gedrukte notulen te verwijzen. Hier zij slechts het volgende aangestipt.

Van de Bijdragen verschenen twee deelen: het $9^{\text {de }}$ en $10^{\text {de }}$ van de Vde volgreeks. Het eerste bevat eene uitvoerige studie van Prof. Mr. L. W. C. van den Berg, over de inlandsche rechtsbronnen van Zuid-Sumatra. In het andere deel zijn den lezers aangeboden verschillende opstellen van taalkundigen aard, waaronder de voortzetting der "Sangireesche teksten" van Dr. Adriani en der vertaling van Jâtakamâlâ door Prof. Speyer, benevens eene uitvoerige bijdrage tot de geschiedenis van Sumatra's Westkust, door ons medelid P. H. van der Kemp.

Afzonderlijk werd vanwege het Instituut gepubliceerd eene door den heer Alb. C. Kruyt vervaardigde Woordenlijst van de Bareëtaal.

In den loop van 1895 zullen verschijnen een door den zendeling M. J. van Baarda samengesteld Woordenboek van de Galelareesche taal, en een naar de nagelaten papieren van wijlen den zendeling J. K. Wijngaarden door Prof. Poensen bewerkte Woordenlijst van de Savoeneesche taal. Door het bestuur zal worden voorgesteld, deze beide werken voor de leden verkrijgbaar te stellen tegen de helft van den boekhandelsprijs.

Ofschoon de uitgaaf niet rechtstreeks, maar toch met medewerking van ons Instituut plaats had, wordt hier herinnerd dat in het laatst van 1894 bij de firma E. J. Brill werd uitgegeven Reisen in den Molukken etc. door Prof. K. Martin. Ook dit werk wordt aan de Instituutsleden voor de helft van den boekhandelsprijs verstrekt.

Ten einde eene eventueele uitgaaf te bevorderen, stond het bestuur eene subsidie toe voor het vervaardigen der teekeningen, behoorende bij een door den heer L. Th. Mayer geschreven werk over het Javaansche volksleven.

Uit een en ander moge de gevolgtrekking gerechtvaardigd zijn, dat het Instituut in het afgeloopen jaar met vrucht is werkzaam geweest voor de Indische taal-, land- en volkenkunde, en dat ook het thans aangevangen jaar eene goede werkzaamheid belooft.

Het verheugt ons, hier te kunnen mededeelen dat er gegrond uitzicht bestaat op het verkrijgen van eenen gedrukten Catalogus van onzen boekenschat. Nadat nl. de Secretaris van het Indisch 
Genootschap, de heer J. Boudewijnse, den catalogus van die instelling had voltooid, verklaarde hij zich bereid, ook de uitgebreide bibliotheek van het Instituut te catalogiseeren. Dit welwillend aanbod werd dankbaar aanvaard, en wij hopen thans binnen een niet te lang tijdsverloop onzen leden eenen geheel bijgewerkten, gecombineerden catalogus van beide instellingen te kunnen aanbieden.

Op ons voorstel werd, onder toekenning eener Regeeringssubsidie, de mogelijkheid geopend om afschriften te erlangen van de in het India Office te Londen aanwezige, voor onze koloniale geschiedenis belangrijke bescheiden over de jaren 1603-1830. De heer W. Roosegaarde Bisschop, tijdelijk aan het India Office werkzaam, verklaarde zich welwillend bereid daartoe namens ons bestuur op te treden. Doch wij vreezen thans, dat zijne aanwezigheid te Londen nog slechts van korten duur zal zijn, en dat het doel dus niet zoo gemakkelijk zal kunnen worden bereikt als wij aanvankelijk meende te kunnen verwachten.

Op de Internationale Tentoonstelling te Antwerpen werden de door het Instituut uitgegeven werken ingezonden. Dat zij hier de aandacht niet ontgingen, blijkt uit het feit dat het Instituut met twee gouden medailles werd bekroond.

Omtrent den financieelen toestand onzer Instelling mogen de volgende mededeelingen dienen.

De balans wijst als bedrag der "activa" aan een cijfer van f 51.358.93, tegen f 50.200 .31 op ult ${ }^{\circ}$ December 1893; het Instituut is alzoo in zijne bezittingen vooruitgegaan met f 1158.62 . Dit resultaat mag zeker bevredigend worden genoemd, wanneer wij in aanmerking nemen dat de leden, behalve de gewone Bijdragen, nog een afzonderlijk deel Bijdragen, benevens eene woordenlijst der Bareëtaal ontvingen.

Het evengenoemd eindcijfer der Balans kan worden gesplitst in de volgende posten:

Gebouw van het Instituut . . . . . . . . . f 20.000.Meubilair .

Bibliotheek

Boekenfonds .

13 Obl. $32_{2}^{\prime}$ pCt. Ned. Werk. schuld. . . . . . - 13.000.-

Saldo in kas. 
Op zich zelf beschouwd, verkeert onze Instelling alzoo voorzeker in bloeienden toestand. Doch met het oog op de toekomst kunnen wij daarmede niet tevreden zijn; immers, bij de gestadige uitbreiding onzer Bibliotheek moet binnen een niet ver verwijderd tijdstip het oogenblik komen waarop wij moeten besluiten tot het betrekken van een grooter gebouw, dat ook door de voor meubileering, onderhoud enz. noodige uitgaven hoogere geldelijke eischen stelt. Van den anderen kant mag, zal het Instituut aan zijne bestemming blijven beantwoorden, niet bezuinigd worden op de uitgaven, die voor de bevordering der kennis van de Taal-, Land- en Volkenkunde van Nederlandsch Indie noodig zijn. Blijft alzoo een zuinig beheer plicht, - het belang der Instelling vordert tevens, dat zij, die vermeerdering van de kennis onzer schoone koloniën waardeeren, er prijs op stellen, in de rijen harer leden een plaats in te nemen. Alleen wanneer ons ledental nog belangrijk toeneemt, zijn wij zeker dat het Instituut, in ruimer woning gehuisvest, ook op wetenschappelijk gebied zijn goeden naam met eere zal blijven dragen.

Hierbij moet ons eene klacht van het hart, n.l. dat meerdere Indische leden, na hun loopbaan in Indië te hebben volbracht, zich bij terugkeer in Europa haasten, voor hun lidmaatschap te bedanken. In Indië beklaagt men zich soms, dat men in Nederland zoo weinig belangstelling toont voor al wat op Indië betrekking heeft; maar te dikwijls moeten wij ervaren, dat de oud-Indiërs in Nederland in dat opzicht een betreurenswaardig voorbeeld geven.

Gelukkig zijn er vele anderen, die dit verwijt niet verdienen. Wij hopen zeer, en eindigen met dezen wensch ons verslag, dat het aantal dergenen, die den arbeid van het Instituut waardeeren en steunen, bij voortduring moge aangroeien, zoodat onze Vereeniging, door de kracht die van haar uitgaat, een eereplaats verwerft onder al hare zusteren. 


\section{ALGEMEENE VERGADERING,}

Zatelidag 23 FEBRUARI 1895.

Aanwezig zijn de bestuursleden: der Kinderen (voorzitter), Kern (ondervoorzitter), J. H. de Groot, (penningmeester), Canne, van der Lith, Poensen, Niemann, van Limburg Stirum en Kielstra (secretaris); voorts de gewone leden A. J. Spaan, Heeres, L. W. C. van den Berg, Fokker, Matthes, de Clereq, Hooijer, von Saher, Serrurier en J. L. van Gennep.

Het Bestuurslid Pijnacker Hordijk heeft bericht gezonden, verhinderd te zijn de vergadering bij te wonen.

De voorzitter opent de vergadering met een hartelijken welkomstgroet aan de aanwezige leden.

De notulen der Algemeene Vergadering van 24 Februari 1894, voorloopig goedgekeurd in de bestuursvergadering van 19 Mei 1894, worden definitief gearresteerd.

De Secretaris leest het door het Bestuur vastgesteld jaarverslag over 1894, dat tot geene opmerkingen aanleiding geeft. De Penningmeester licht de daarin opgenomen eijfers nader toe.

De heer de Clereq, met den heer Hooijer door het Bestuur uitgenoodigd de rekening en verantwoording van den Penningmeester na te zien, verklaart ook namens den heer Hooijer alles in volkomen orde te hebben bevonden, en stelt de vergadering voor, den penningmeester acquit en decharge te verleenen onder dankbetuiging voor zijn nauwkeurig en zorgvuldig beheer.

Dienovereenkomstig wordt besloten.

Eenige opmerkingen, door den heer de Clereq gemaakt omtrent een paar uitgaafposten, worden door den secretaris en den penningmeester toegelicht.

Ingevolge art. 8 van het Reglement treden de HH. der Kinderen, Niemann en Kielstra als bestuursleden af, terwijl alleen laatstgenoemde 
herkiesbaar is. Ter vervulling der vacatures, en tevens ter vervanging van wijlen Dr. Wijnmalen, worden door de vergadering, uit de door het bestuur aangeboden drietallen, gekozen de HH. Dr. J. Spanjaard, Mr. L. W. C. van den Berg, Dr. K. Martin en E. B. Kielstra. De heeren van den Berg en Kielstra, ter vergadering aanwezig, verklaren de benoeming te aanvaarden; aan de HH. Spanjaard en Martin zal van de op hen gevallen keuze worden kennis gegeven.

De President wijdt een woord van hulde aan het aftredend bestuurslid Niemann, die nu wederom vier jaren zijne beste krachten aan den werkkring van het Instituut heeft gewijd, en zegt den Secretaris in het bijzonder dank voor den steun, hen tijdens de langdurige ziekte van Dr. Wijnmalen, als wd. Secretaris verleend.

De Voorzitter herinnert dat, volgens eene mededeeling in het Verslag, vanwege het Instituut zullen worden uitgegeven een Galelareesch woordenboek en eene woordenlijst der Savoeneesche taal, en stelt thans voor, overeenkomstig art. $13,2^{\mathrm{e}}$ al. van het Reglement, te bepalen dat deze werken alleen voor de leden verkrijgbaar zullen zijn tegen de helft van den boekhandelsprijs.

Zonder discussie goedgekeurd.

De Secretaris leest de lijst der nieuwbenoemde Instituutsleden (zie notulen der Bestuursvergadering van 16 Februari 1895).

De Voorzitter, er op wijzende dat art. $10,4^{\mathrm{e}}$ lid sub 2 van het Reglement de machtiging der Algemeene Vergadering eischt voor het koopen en verkoopen van onroerend goed, brengt in herinnering dat reeds herhaaldelijk de wenschelijkheid ter sprake kwam om, ten behoeve der steeds aangroeiende bibliotheek, een ruimer gebouw te betrekken. Om financieele redenen zal het bestuur geneigd zijn, daarmede zoolang mogelijk te toeven; maar het is wenschelijk, dat het de evenbedoelde machtiging thans verkrijge om niet verhinderd te zijn, van eene zich in de eerstvolgende jaren wellicht voordoende gunstige gelegenheid gebruik te maken. In het bijzonder bij publieken verkoop van eenig geschikt gebouw is de voorafgaande bijeenroeping eene buitengewone algemeene vergadering, zoowel ter handhaving der noodige geheimhouding als wegens den beschikbaren tijd, niet wel mogelijk.

Zonder discussie wordt de gevraagde machtiging verleend. 
De heer Serrurier brengt in herinnering dat, volgens de notu] van de bestuursvergadering van 21 October 1893, door het bestv bezwaar werd gemaakt mede te werken tot de uitgaaf van $\epsilon$ werk over de Garĕbĕgs te Djocjokarta, door Dr. Groneman.

Dat werk is thans gereed, en bevat naar de meening van d Spreker een schat van ethnographische mededelingen; hij zou c het bestuur wel in overweging willen geven, nader te besliss of zijnerzijds de uitgaaf niet zoude kunnen worden bevorderd.

Het lid de Clereq ondersteunt dit voorstel. ook op grond c overweging dat de Bijdragen voor een goed deel opstellen v taalkundigen aard bevatten die, hoe belangrijk ook, de mee: leden niet boeien, zoodat meer verscheidenheid gewenscht is.

De Voorzitter twijfelt niet, of het Bestuur zal gaarne bert zijn de uitgaaf van het opstel van Dr. Groneman nader overwegen.

Nadat nog eene gedachtenwisseling heeft plaats gehad tussch de HH. de Clereq, Kern, van den Berg en Kielstra omtrent mogelijkheid or meer medewerking op historisch en ethnographis gebied uit Indië te verkrijgen, erlangt de Onder-voorzitter h woord, om den aftredenden Voorzitter namens het bestuur te dank voor de voortreffelijke wijze, waarop door hem vier jaren lang h presidium van het Instituut is gevoerd, en hem de verzekeriı te geven dat de bestuursleden hem gaarne spoedig in hun midden . kan het zijn aan hun hoofd - zullen terugzien.

De Voorzitter is den Onder-voorzitter erkentelijk voor zij vriendschappelijke woorden, en verklaart de beste wenschen blijven koesteren voor het welzijn en den bloei des Instituuts.

De vergadering wordt gesloten.

(Voorloopig vastgesteld in de Bestuursvergadering van $16 \mathrm{Maa}$ 1895). 


\section{BESTUURSVERGADERING,}

ZATERDAG 16 MAART 1895.

Aanwezig de HH. Kern, Pijnacker Hordijk, Martin, Spanjaard, Canne, van den Berg, van der Lith, Poensen, J. H. de Groot en Kielstra; afwezig, met kennisgeving, de heeren J. J. M. de Groot en van Limburg Stirum.

Van de HH. Martin en Spanjaard is bericht ingekomen dat zij bereid zijn het hun door de algemeene vergadering opgedragen lidmaatschap van het bestuur te aanvaarden. Zij worden door den heer Kern, als oudste in benoeming, verwelkomd.

De notulen der vorige bestuursvergadering en der algemeene vergadering worden gelezen en goedgekeurd, - wat de laatstbedoelde betreft behoudens de nadere goedkeuring der volgende algemeene vergadering.

Tot voorzitter, ondervoorzitter, penningmeester en secretaris worden resp. gekozen de heeren Kern, Pijnacker Hordijk, J. H. de Groot en Kielstra, die zich tot de vervulling dier functiën bereid verklaren. De heer Kern neemt den. voorzittersstoel in.

\section{Ingekomen zijn :}

a. Bericht van de HH. T. M. C. Asser, Jhr. A. W. van Borssele, L. W. C. Gerlach, Dr. C. C. Hesseling, Mr. H. F. Hesselink van Suchtelen, Mr. Ph. Kleintjes, J. A. van der Loeff, Mr. A. Loudon, Prof. Dr. S. A. Naber, Mr. H. A. Nebbens Sterling, Mr. C. F. Pahud de Mortagnes, M. H. J. Plantenga, Jhr. Mr. D. Roëll, J. H. Romswinckel, L. H. Ruyssenaers, F. D. Graaf Schimmelpenninck, Mr. E. A. Smidt, Mr. F. A. H. von Weckherlin, L. Wessels, Jhr. H. M. van der Wijek en H. Zondervan, dat zij de benoeming tot Instituutslid aannemen.

b. enz. 
c. Bericht van de leden Dr. W. F. van Vliet en Dr. J. Mendels, dat zij met het einde van het jaar 1895 hun lidmaatschap wenschen te doen eindigen.

d. Idem (door tusschenkomst van den Commissaris Dr. Brandes te Batavia), van de leden F. Twiss en Dr. J. C. C. W. van Nooten.

e. Opgaven van veranderde adressen van de leden Machielsen, Schadee, Kalshoven en Wiercx.

f. Dankbetuiging van de Anthropologische Gesellschaft te Weenen voor de belangstelling, door het Instituut betoond bij gelegenheid van haar 25-jarig bestaan.

Notificatie.

g. Voorstel van de Société d'études Coloniales te Brussel ter ruiling van de wederzijdsche uitgaven.

$\mathrm{Na}$ gedachtenwisseling wordt besloten, aan de Société mede te deelen dat, naar het voorkomt, tusschen den werkkring van haar en van het Instituut nagenoeg geen punt van overeenkomst bestaat, en dat zij het beoogde doel beter bereiken zal door haar voorstel te richten tot het Indisch Genootschap.

h. Verslag van de Archaeologische Vereeniging te Djoejokarta voor 1894.

Notificatie.

De Secretaris brengt ter tafel het in de Algemeene Vergadering door Dr. Serrurier bedoeld opstel van Dr. Groneman over de Garĕbĕg's te Djocjokarta.

In handen gesteld van de bestuursleden Poensen en Canne, met verzoek in de volgende vergadering te adviseeren omtrent de uitgaaf vanwege het Instituut.

Op voorstel van den Voorzitter wordt tot lid van het Instituut benoemd de heer P. S. van Ronkel te Leiden.

De Penningmeester deelt mede, dat de bibliotheken van het Indisch Genootschap en van het Instituut, benevens het boekenfonds van het Instituut thans te zamen zijn verzekerd tegen brand voor if $35,000$. .

De vergadering wordt gesloten. 


\section{$360^{\circ}$ BESTUURSVERGADERING,} ZATERDAG 20 APRIL 1895.

Aanwezig de HH. Kern (Voorzitter), Pijnacker Hordijk (Ondervoorzitter), Spanjaard, Canne, van den Berg, Poensen, van der Lith, J. J. M. de Groot, J. H. de Groot (Penningmeester) en Kielstra (Secretaris).

Afwezig, met kennisgeving, de HH. Martin en van Limburg Stirum.

De notulen der vorige vergadering worden gelezen en goedgekeurd.

De Voorzitter herinnert aan het verlies, door het vaderland en de wetenschap geleden door den dood van het Eerelid des Instituuts, Professor Veth. Hij stelt voor, aan de weduwe een brief van rouwbeklag te doen toekomen.

Conform besloten.

\section{Ingekomen :}

$1^{\circ}$. Bericht van de HH. A. K. Derx te Siboga, P. S. van Ronkel te leiden en J. Baron Fagel te Avegoor, (Ellecom, bij Dieren), tot aanneming van het lidmaatschap.

2o. enz.

$3^{\circ}$. bericht van de leden K. L. van Schouwenburg te Leiden en J. H. Anschütz te Padang, tot opgaaf van hun tegenwoordig adres.

$4^{\circ}$. bericht van de leden L. C. Rombach en E. P. C. Sol, dat zij met het einde des jaars voor hun lidmaatschap wenschen te bedanken.

Notificatie.

De Secretaris draagt tot lid voor den heer B. M. Goslings, $1^{\mathrm{e}}$ luitenant der infanterie van het Oost-Indisch Leger.

De heer Goslings wordt met algemeene stemmen benoemd.

Van den Bibliothecaris van het Muséum d'histoire naturelle te Parijs is een schrijven dd. 20 Maart jl. ontvangen, waarin wordt voorgesteld ruiling der wederzijdsche uitgaven. 
Aangezien de werkkring van het Instituut geheel valt buiten dien van het Museum, meent de vergadering bezwaar te moeten maken, aan dat voorstel gevolg te geven.

Door den hoogleeraar Dr. G. Schlegel is, bij schrijven van 2 April jl. aan het Instituutsbestuur het verzoek gedaan, de uitgaaf eener vertaling van een door den Chineeschen staatsminister Tchan-youeh geschreven voorrede bij eene reisbeschrijving van den boeddhistischen pelgrim Hun tsjwang door eene subsidie te steunen.

$\mathrm{Na}$ uitvoerige gedachtenwisseling wordt besloten aan dit verzoek niet te voldoen, aangezien bedoelde vertaling, geheel van Chineesch-philologischen aard, te zeer valt buiten den werkkring des Instituuts (art. 2 van het Reglement).

Door het bestuurslid Canne wordt, ook namens den heer Poensen, verslag uitgebracht over het werk van Dr. Groneman over de Garěbĕgs te Djocjokarta.

De conclusie van het verslag luidt: bedoeld werk in de Bijdragen op te nemen, behoudens eenige verkortingen, en daarbij de platen te reproduceeren in photozincographie.

Dienovereenkomstig wordt besloten; den Secretaris wordt opgedragen, omtrent de bedoelde verkortingen met den heer Serrurier, of, zoo noodig, met den auteur in overleg te treden.

De Penningmeester deelt mede dat thans alle Indische contributies van 1894 zijn geïnd, en dat hij deswege van de firma G. Kolff \& $C^{\circ}$. eene remise van $f^{\prime} 2184.98^{5}$ heeft ontvangen.

Naar aanleiding van zijn verslag worden uit de ledenlijst afgevoerd de HH. Senn van Bazel (overleden) en Hohman, wiens adres onbekend is.

De vergadering wordt gesloten.

\section{$361^{\mathrm{e}}$ BESTUURSVERGADERING,} ZATERDAG 25 MEI 1895.

Aanwezig de heeren: Kern (Voorzitter), Canne, J. J. M, de Groot, van den Berg, Poensen, van der Lith, van 
Limburg Stirum, Spanjaard, J. H. de Groot (Penningmeester) en Kielstra (Secretaris).

Afwezig, met kennisgeving, de heeren Pijnacker Hordijk en Martin.

De notulen der vergadering van 20 April 1895 worden gelezen en goedgekeurd.

Ingekomen zijn :

$1^{\circ}$. berichten van de HH. Mr. P. J. C. Hennequin, Mr. S. van Houten, Mr. W. van der Kaay, W. Prinzen, F. M. Knobel, J. J. Bischoff, Mr. H. K. J. van Deinse, Mr. C. W. Kist, P. J. F. Louw, J. J. K. de Moulin, A. van der Gon Netscher, J. H. B. Oomen en Mr. J. Paulus, dat zij het lidmaatschap des Instituuts aanvaarden.

2. opgaaf van veranderd adres van het lid H. J. A. Raadt van Oldenbarnevelt.

$3^{\circ}$. bericht van het overlijden van het correspondeerend lid J. C. Neurdenburg, het lid Mr. W. K. baron van Dedem, het lid Dr. J. K. Jacobs en den heer M. P. Chagas, secretaris van de Académie royale des Sciences te Lissabon.

$4^{\circ}$. enz.

$5^{\circ}$. dankbetuiging van Mevrouw Veth-van der Koogh voor de deelneming, door het Instituut betoond bij het overlijden van haren echtgenoot Dr. P. J. Veth.

Notificatie.

De Secretaris draagt voor tot lid van het Instituut, den heer Ko-mo-an, koopman te Djocjokarta.

De heer Ko-mo-an wordt met algemeene stemmen benoemd.

De Secretaris deelt mede dat door hem in ontvangst genomen zijn de medailles en bijbehoorende diploma's, aan het Instituut toegekend door de jury van de ten vorigen jare te Antwerpen gehouden wereldtentoonstelling.

Namens de heer K. F. Holle is door het lid Mr. N. P. van den Berg, aan het Instituut toegezonden eene kaart van den aard van het grondbezit op Java, met bijbehoorenden staat.

Voor deze toezending is bereids dank betuigd. 
Door het buitenlandsch lid Aristide Marre is het Instituut aangeboden een exemplaar van den tweeden druk zijner Grammaire Malgache.

Den Schrijver zal den dank van het Bestuur worden aangeboden; zijn werk is opgenomen in de Bibliotheek.

Van Mr. N. P. van den Berg is ontvangen zijn advies omtrent het opstel van den heer Reesse over den suikerhandel van Amsterdam tot 1813, waarvan de conclusie luidt: dat het werk te weinig betrekking heeft op de geschiedenis van Nederlandsch-Indië om voor eene uitgaaf vanwege het Instituut te kunnen worden aanbevolen, hoe belangrijk het overigens ook mag worden genoemd.

Overeenkomstig dit advies wordt besloten, tot de uitgaaf niet over te gaan. Van deze beslissing zal den heer Reesse kennis worden gegeven, en aan $\mathrm{Mr}$. van den Berg zal, onder dankbetuiging voor zijne welwillende bemoeiïngen, vergunning worden gevraagd om een afschrift van zijn advies aan den heer Reesse ter hand te stellen.

De Secretaris doet het voorstel, met wijziging van het in de vorige bestuursvergadering genomen besluit, de uitgaaf van het werk van Dr. Groneman over de Garĕbĕgs niet in de Bijdragen, maar afzonderlijk, in het formaat der platen, te doen uitgeven.

Tot dit voorstel wordt hij geleid door de volgende overwegingen :

$1^{0}$. zal daardoor de publicatie van eenige opstellen, waarvan de spoedige plaatsing den schrijvers aangenaam wezen zoude, niet worden vertraagd;

$2^{\circ}$. zal het werk van Dr. Groneman, wegens den arbeid aan den druk der platen verbonden en vooral omdat de daarbij behoorende platte grond van den Kraton te Djocjokarta nog uit Indië wordt verwacht, niet omstreeks 1 Juli gereed kunnen zijn;

$3^{\circ}$. zullen dan de platen niet gevouwen of in afzonderlijke portefeuilles verzonden behoeven te worden; het vouwen der platen zou deze lichtelijk beschadigen, en het verstrekken der portefeuilles zou de kosten der uitgaaf met ce. f 130 . - doen toenemen.

$\mathrm{Na}$ discussie wordt dit voorstel met algemeene stemmen goedgekeurd.

Niets meer aan de orde zijnde, wordt de vergadering gesloten. 